THE MEDIAEVAL MIND 

THE

\section{MEDIAEVAL MIND}

\section{A HISTORY OF THE DEVELOPMENT OF THOUGHT AND EMOTION IN THE MIDDLE AGES}

B Y

HENRY OSBORN TAYLOR

IN TWO VOLUMES

VOL. II

FOURTH EDITION

CAMBRIDGE, MASSACHUSETTS HARVARD UNIVERSITY PRESS 
Fifth printing of the fourth edition 